
www.globaljournalseries.com, Email: info@globaljournalseries.com

\title{
ASSESSMENT OF SHEA FRUIT PROCESSORS IN NIGER STATE FOR IMPROVED LIVELIHOOD AND ENTREPRENEURIAL ACTIVITIES
}

\author{
O. SOLOMON, I. L. GOLD AND L. IGENE
}

(Received 23 August 2017; Revision Accepted 20 November 2017)

\begin{abstract}
The Shea tree is indigenous to sub-Saharan Africa, and generally found in semi-arid to arid north of the humid forest zone. Shea fruit processing is a common production activity in rural areas of Niger State. This study aimed at having an overview of Shea fruit processors as a means of identifying areas of intervention for improved productivity and their livelihood. Specific objectives were to assess the socio-economic characteristics, ascertain average monthly income from Shea processing, identify sources of labour for Shea processing, examine the social infrastructures available to processors, assess the production capacity of the processors and determine constraints to Shea butter production activities in the study area. A multi-stage sampling technique was employed to select 80 Shea butter processors for the study while a well structured questionnaire was used for data collection. The study revealed that the respondents, all women, were married $(96.1 \%)$ and within their active ages. The women all belong to one or more groups. Main sources of labour for processing of Shea butter were Family $(75 \%)$ and communal $(65.8 \%)$; All the respondents find the current Shea butter processing methods difficult. Chi-square analysis indicates that respondents' years of experience in processing" $\left(x^{2}=17.18 ; p<0.05\right)$ and "household size" $\left(x^{2}=12.79 ; p<0.05\right)$ have significant association with respondents' level of butter production. The study therefore calls for better exposure of the processors through entrepreneurial skill acquisition scheme, to improved technique of Shea processing for better quality nuts/ butter production and principles of agribusiness.
\end{abstract}

KEYWORDS: Shea tree, rural livelihood, Shea processing, Quality nuts/butter, Ready market.

\section{INTRODUCTION}

The Shea-nut tree, Vitellaria paradoxa Gaertn, is a major component of the woody flora of the Sudan and Guinea savannah vegetation zones of sub-Saharan Africa (Lovett and Haq, 2000). The Shea tree is indigenous to sub-Saharan Africa, and generally only found in semi-arid to arid north of the humid forest zone (CABI, 2003). The species' range forms an almost unbroken belt approximately $5,000 \mathrm{~km}$ long by $500 \mathrm{~km}$ wide from Senegal to Uganda (Bonkoungou, 1987). The Shea tree is a perennial and deciduous tree which occurs in the wild mainly on dry open slopes. The gestation period varies from 16-20 years depending on the species and tree yield are erratic, varying from year to year and between populations.

The most important product of $V$. paradoxa is the Shea butter (francophone: le beurre de Karité), which is extracted from Shea dried kernels or nuts. This oil is widely utilized locally for domestic purposes such as cooking, as a skin moisturizer and as an illuminant (Lovett and Haq, 2000). Shea butter is also utilized commercially as an ingredient in cosmetic and pharmaceutical (Abbiw, 1990). The Shea tree is a perennial and deciduous tree which occurs and grows wildly and naturally. In relation to the value chain, shea processing and trade are the major activities of the industry in Nigeria. The butter though crude and of poor quality, is often used as cooking oil, creams for new born, arthritic pain reliever when mixed with kerosene, heat absorbent in cases of high body temperature, lip gloss, hair conditioner etc. Most of the butter produced is used in homes while a small fraction, sold in the market place. Over a long period of time very little efforts were made to improve the quality of shea butter production in the country. In recent times, Government and some non-governmental organizations initiated some programmes at improving the quality of processed shea nut because of the commercial importance of its product in the international market and the intension of utilizing shea processing as an instrument of poverty alleviation among women who incidentally are the major actors in the value chain and nutrition in Africa. High quality Shea butter should have a free fatty acid content of less than 1 percent and dirt content of less than 0.1 percent. Niger State is a major shea production area and has a very concentration of Shea fruit processors where the activities are known to be tied to laborious protocols.

This survey was conducted to assess the current status of shea butter processors in the study area for the purpose of identifying ways of enhancing rural livelihood through improved post-harvest handling, Shea butter processing quality in Nigeria

O. Solomon, Extension Division, Nigerian Institute for Oil Palm Research, Benin City, Edo State, Nigeria.

I. L. Gold, Biochemistry Division, Nigerian Institute for Oil Palm Research, Benin City, Edo State, Nigeria.

L. Igene, Extension Division, Nigerian Institute for Oil Palm Research, Benin City, Edo State, Nigeria. 


\section{Objectives of the study}

The general objective of the study is to assess the current status of shea butter processors in the study area for the purpose of identifying ways of enhancing rural livelihood through improved post-harvest handling, Shea butter processing quality in Nigeria

\section{Specific objectives}

The specific objectives are to;

1. Determine the socio-economic characteristics of the respondents

2. Identify respondent's source of labour for Shea processing activities.

3. Assess the Sheanut production capacity of the respondents.

4. Determine the quantity of Shea butter production per month by respondents.

5. Ascertain respondent's income generation activities.

6. Examine the social infrastructures available in the study area.

7. Determine the constraints to Shea butter production activities in the study area.

The only hypothesis of the study stated in the null form is as presented below.

$\mathbf{H}_{0}$ : There is no significant relationship between respondents' selected socio-economic characteristics and their level of butter production.

\section{METHODOLOGY}

The study was carried out in Niger State of Nigeria. Niger State is located in the North Central agroecological zone of Nigeria with a land area of 74,244 square kilometres and a population of 3,950,249 (National Population Commission, 2006). The State lies between latitudes $8^{\circ} 20^{\prime} \mathrm{N}$ and $11^{\circ} 30^{\prime} \mathrm{N}$ and longitude $3^{\circ} 30^{\prime} \mathrm{E}$ and $7^{\circ} 20^{\prime} \mathrm{E}$. Niger State is bounded by Kaduna State and FCT in the North-East and South-East respectively; Zamfara State to the North, Kebbi State in the West, Kogi State in the South and Kwara State in the South West, while the Republic of Benin boarders the State in the North West. Niger State experiences distinct dry and wet seasons with annual rainfall varying from $1,100 \mathrm{~mm}$ in the northern parts to $1,600 \mathrm{~mm}$ in the southern parts. Generally, the fertile soil and hydrology of the State permits the cultivation of most of Nigeria's staple crops and still allows sufficient opportunities for grazing, fresh water fishing and forestry development. Niger State has the highest natural grove of the Shea tree in Nigeria
A multi-stage sampling technique was employed to select 80 Shea butter processors in 4 Local Government Areas of Niger State. The LGAs, Lapai, Bosso, Gbako and Katcha, were purposively selected out of the 25 LGAs in the state due to the very high prevalence of Shea butter producers. Secondly, from each of the selected LGAs, 2 communities were randomly selected. Finally, 10 Shea butter processors were also randomly selected from each of the selected communities from sample frame provided by the PWDO, (Principal Women Development Officer) thus, giving a sample size of 80 respondents. Data were collected with the use of a well-structured questionnaire and was administered with the assistance of 4 PWDOs in each of the selected LGAs.

Descriptive statistics such as frequencies and percentages were used in analysing the data collected while chi-square was used to test the only hypothesis of the study.

\section{RESULTS AND DISCUSSION}

Socio-Economic Characteristics of the Respondents Results in Table 1 showed the distribution of farmers according to their socio-economic characteristics. A higher proportion (63.2\%) of the Shea butter processors were between the ages of 21 and 40 years, all female married (96.1\%) and with no formal education $(87 \%)$. The implication of this is that majority of the respondents were relatively young, within their active ages and cannot easily access simple extension publications due to their poor level of education. Majority of the respondents $(92.1 \%)$ were Muslims and had house-hold size of $1-10(71.1 \%)$. This result is an indication that observed household could be a reservoir or good source of labour for Shea processing activities in the study area. Table 1 also showed that majority $(94.7 \%)$ of the respondents were members of one cooperative society or the others and main benefits respondents derive from their membership of the cooperatives are credit facility $(47 \%)$ and common or communal labour usage (38\%). A higher proportion $(32.9 \%)$ of the respondents had good butter processing experience (11-15 years). In addition to the processing of Shea butter, other occupation the respondents engaged in, included petty trading (54\%) and farming $(42 \%)$. Only 3 percent of the respondents were civil servants. Furthermore, all (100\%) the respondents owned their live-in houses with 72 percent indicating mud with zinc roof as type of houses owned. Again, contrary to expectations, about 62 percent of the respondents had 1 to 5 children in school and most $(86 \%)$ of the respondents had the ability to pay children school fees. 
Table 1: Socio-Economic Characteristics of Respondents.

\begin{tabular}{|c|c|c|}
\hline Socio-Economic Characteristics & Frequency & Percentage \\
\hline \multicolumn{3}{|l|}{ Age } \\
\hline Below 20years & 2 & 2.6 \\
\hline $21-30$ & 25 & 32.9 \\
\hline $31-40$ & 23 & 30.3 \\
\hline $41-50$ & 22 & 28.9 \\
\hline Above 50 & 4 & 5.3 \\
\hline \multicolumn{3}{|l|}{ Sex } \\
\hline Male & - & - \\
\hline Female & 76 & 100 \\
\hline \multicolumn{3}{|l|}{ Marital Status } \\
\hline Married & 73 & 96.1 \\
\hline Single & 2 & 2.6 \\
\hline Widow & 1 & 1.3 \\
\hline \multicolumn{3}{|l|}{ Household size } \\
\hline $1-5$ & 29 & 38.2 \\
\hline $6-10$ & 27 & 35.5 \\
\hline $11-15$ & 6 & 7.9 \\
\hline $16-20$ & 9 & 11.8 \\
\hline $21 \&$ above & 5 & 6.6 \\
\hline \multicolumn{3}{|l|}{ Religion } \\
\hline Christianity & 6 & 7.9 \\
\hline Muslim & 70 & 92.1 \\
\hline \multicolumn{3}{|l|}{ Educational level } \\
\hline No formal education & 66 & 87 \\
\hline Primary & 8 & 11 \\
\hline Secondary & - & - \\
\hline Tertiary & 1 & 1 \\
\hline Quoranic & 1 & 1 \\
\hline \multicolumn{3}{|l|}{ Member of cooperative } \\
\hline Yes & 72 & 94.7 \\
\hline No & 4 & 5.3 \\
\hline \multicolumn{3}{|l|}{ *Benefits of membership } \\
\hline Credit linkage & 31 & 47 \\
\hline Common labour usage & 29 & 38 \\
\hline Market information & 16 & 21 \\
\hline Social networking & 14 & 18 \\
\hline \multicolumn{3}{|l|}{ Experience in Processing (Yr) } \\
\hline Less than 5 & 3 & 3.9 \\
\hline $6-10$ & 23 & 30.3 \\
\hline $11-15$ & 25 & 32.9 \\
\hline $16-20$ & 12 & 15.8 \\
\hline More than 20 & 13 & 17.1 \\
\hline \multicolumn{3}{|l|}{ Other occupation } \\
\hline Farming & 32 & 42 \\
\hline Civil servant & 2 & 2.6 \\
\hline Petty trading & 41 & 54 \\
\hline Knitting & 1 & 1.3 \\
\hline \multicolumn{3}{|l|}{ House Ownership } \\
\hline Yes & 76 & 100 \\
\hline No & - & - \\
\hline \multicolumn{3}{|l|}{ Types of house owned } \\
\hline Mud with thatched roof & 2 & 2.6 \\
\hline Mud with zinc roof & 55 & 72 \\
\hline Cement with zinc roof & - & - \\
\hline Cement with thatched roof & 19 & 25 \\
\hline \multicolumn{3}{|l|}{ No of children in school } \\
\hline $1-5$ & 47 & 62 \\
\hline $6-10$ & 16 & 21 \\
\hline $11-15$ & 2 & 2.6 \\
\hline Above 15 & - & - \\
\hline None & 11 & 14 \\
\hline \multicolumn{3}{|l|}{ Ability to pay school fees } \\
\hline Yes & 65 & 86 \\
\hline No & 11 & 14 \\
\hline
\end{tabular}


Sources of labour for Shea Processing Activities

Findings in Table 2 revealed that major sources of labour for Shea processing activities in the study area were the family $(75 \%)$ and Communal labour $(65.8 \%)$. Use of commercial labour (1.3\%) and hired labour
$(2.6 \%)$ were the least sources of labour used in Shea nut processing activities. This confirms extensive use of the social form of labour in Shea nut processing activities in the study area.

Table 2: Distribution of Respondents according to Sources of Labour for Shea Processing Activities

\begin{tabular}{|l|c|c|}
\hline Sources & *Frequency & *Percentage \\
\hline Hired & 2 & 2.6 \\
Family & 57 & 75.0 \\
Communal & 50 & 65.8 \\
Commercial & 1 & 1.3 \\
Both hire \& family & 3 & 3.9 \\
Both Family\& commercial & 13 & 17.1 \\
\hline
\end{tabular}
$\mathrm{n}=76$

Source: Field survey, 2015

${ }^{*}=$ Multiple response

\section{Respondents Sheanut Processing Capacity}

As shown on table 3 , a higher proportion of the respondents $(58 \%)$ do not sell Shea kernel but process them into butter. As regards those who sell, main reasons given for the sale were to meet up with payment of children school fees (41\%) and poor market for the Shea butter (34\%). Furthermore, all the respondents $(100 \%)$ find their current Shea butter production processes very difficult and 58 percent of the respondents indicated that there is no ready market for Shea butter produced in the study area. In the same vein, the respondents $(100 \%)$ agreed that with provision of improved processing facilities and ready market for
Shea butter, their Shea butter production capacity will increase significantly. Table 3 also revealed respondents $(89 \%)$ assertion that with improved marketing outlets and ready uptake of Shea butter, their Shea butter production capacity could increase significantly for between 41 and 100 percent. Major input required to increase Shea butter production capacity, as identified by the respondents $(59 \%)$, is improved processing equipment which, apart from reducing drudgery and low level of production, could improve significantly quality of produced butter. This goes to show a prevalence of the use of local traditional methods in processing of Shea butter in the study area.

Table 3: Distribution of Respondents according to Sheanut Processing Capacity

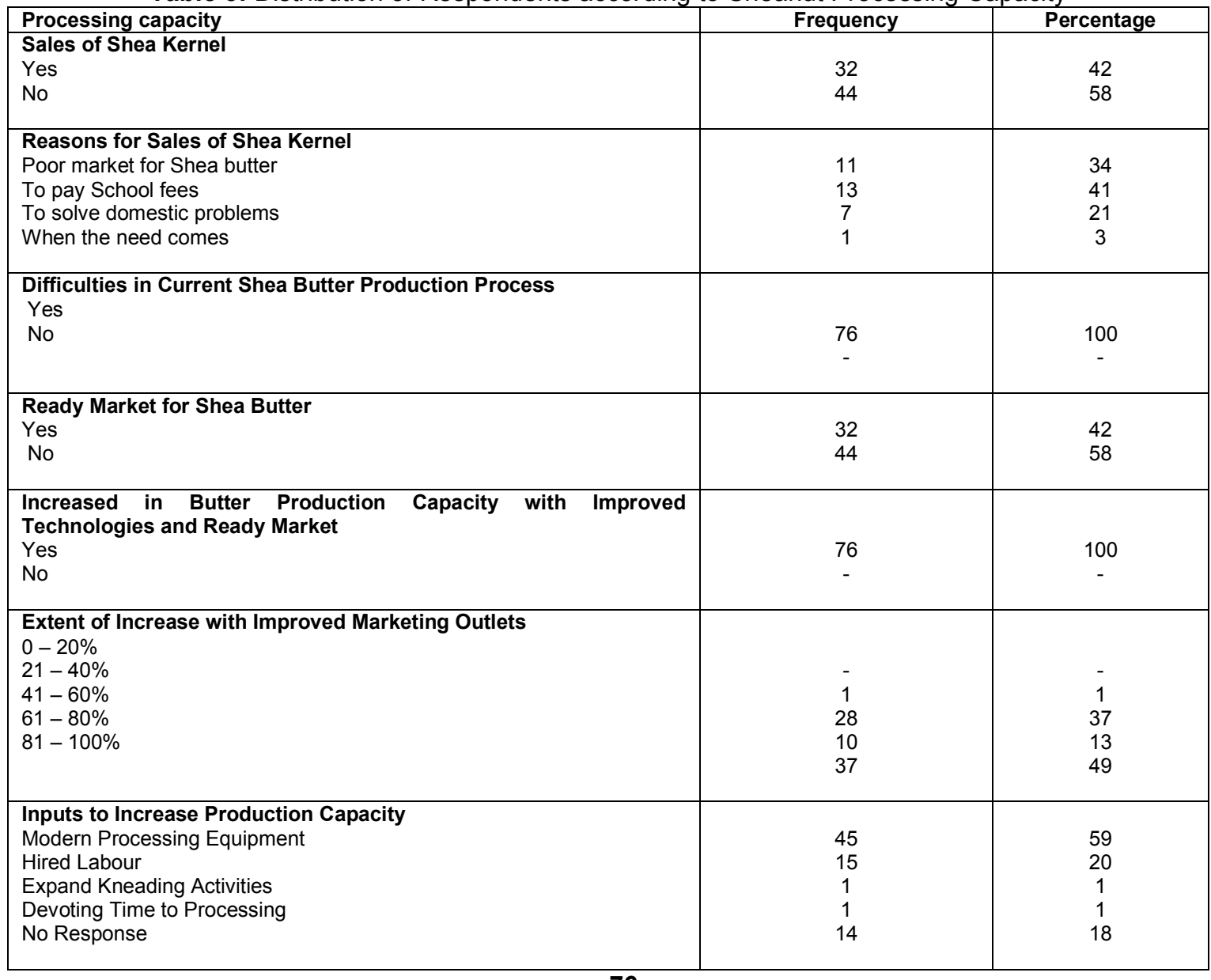

$\mathrm{n}=76$

Source: Field survey, 2015 


\section{Quantity of Shea Butter Produced per Month}

Table 4 showed the quantity of butter produced per month by the respondents. The results revealed that about 63.2 percent of the respondents produce between 10 and $30 \mathrm{~kg}$ of Shea butter per month at the peak period of production. Only about 1.3 percent of the respondents produce above $50 \mathrm{~kg}$ of Shea butter per month during peak production period while about 5.2 percent produce less than $10 \mathrm{~kg}$. These butter production output per month is very low considering the level of work done in the realisation of the butter. Adoption of improved Shea nut processing technologies and introduction of best practices in Shea butter production by the processors could provide needed intervention to improved butter production output.

Table 4: Respondents Shea Butter Production Output per Month

\begin{tabular}{|l|c|c|}
\hline Quantity of Shea Butter Processed per Month (Kg) & Frequency & Percentage \\
\hline Below 10 & 4 & 5.3 \\
$11-20$ & 10 & 13.2 \\
$21-30$ & 38 & 50 \\
$31-40$ & 20 & 26.3 \\
$41-50$ & 3 & 3.9 \\
Above 50 & 1 & 1.3 \\
\hline
\end{tabular}

$n=76$

Source: Field survey, 2015

\section{Respondents Income Generation Activities}

Findings in Table 5 reveal that the respondents in the study area engage in various income generation activities. These activities include Shea fruit processing $(100 \%)$, Petty trading $(51.2 \%)$ and farming $(40.7 \%)$. Shea butter production is a major income generating activity in the study area. About 75 percent of the respondents generate a gross average monthly income of between N6,000 and N30,000 from Shea processing activities. However, a higher proportion $(43.4 \%)$ of the respondents make an average monthly income of between $\mathrm{N} 6,000$ - N10,000 per month from the processing activities. This shows that the respondents make poor returns from Shea processing activities in relation to their input such as labour, time use and difficulties associated with the use of local traditional
Shea processing methods. For example processing a $30 \mathrm{~kg}$ bag of Shea nut using local processing technique would require 3 man/days for 2 days. Dried Shea nuts are roasted, pounded and milled same day while kneading/boiling of the mass, clarification and packaging are done on the second day. These processes are tedious. It is however, noteworthy that only 1.3 percent of the respondents generate above $\mathrm{N} 50,000$ average monthly income from Shea processing activities. Additional meagre incomes are also generated by the respondents from farming and petty trading. Further analysis of the results in Table 5 revealed that the respondents engage more, in a combination of four income generating activities and make average monthly income of $\mathrm{N} 6,000-\mathrm{N} 20,000(69.6 \%)$ and $\mathrm{N} 21,000-$ $\mathrm{N} 35,000$

Table 5: Distribution of Respondents According to Average Monthly Income from Occupational Activities

\begin{tabular}{|c|c|c|c|c|c|c|}
\hline Main occupation & $\begin{array}{c}\text { Involvement } \\
(\%)\end{array}$ & $\leq 5000$ & $\begin{array}{l}6000- \\
20,000\end{array}$ & $\begin{array}{c}21,000- \\
35,000\end{array}$ & $\begin{array}{c}36,000- \\
50,000\end{array}$ & $\begin{array}{l}\text { Above } \\
50,000\end{array}$ \\
\hline Shea processing & 100 & $17(22.4)$ & $33(43.4)$ & $24(31.6)$ & $1(1.3)$ & $1(1.3)$ \\
\hline Farming & 40.7 & $9(11.8)$ & $3(3.9)$ & $16(21.1)$ & $2(2.6)$ & 1(1.3) \\
\hline Civil servant & 2.6 & 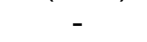 & - & $2(2.6)$ & - & 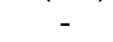 \\
\hline Petty trading & 51.2 & 15(19.7) & $16(21)$ & $8(10.5)$ & - & - \\
\hline Knitting & 1.3 & & 1(1.3) & & - & - \\
\hline & & 41 (53.9) & $43(69.6)$ & $40(65.8)$ & $3(3.9)$ & $2(2.6)$ \\
\hline
\end{tabular}

Source: Field survey, 2015

Social Infrastructures Available in the Community In relation to this study, social infrastructure refers to basic social amenities available within a social setting. The respondents as shown in Table 6, indicated that basic social infrastructural facilities available in the study area included primary school, accessible road and portable hand press borehole water. There are no secondary/tertiary institutions and available health care facilities in the area are few and privately owned. The results revealed the rural nature of the study area. 
Table 6: Availability of Social Infrastructures in the Community

\begin{tabular}{|l|c|c|}
\hline Social infrastructure & *Frequency & Percentage \\
\hline Primary School & 76 & 100 \\
Secondary school & 22 & 30 \\
Tertiary Institution & - & - \\
Health care facility & 30 & 40 \\
Accessible road & 42 & 55 \\
Portable water & 41 & 54 \\
\hline \multicolumn{1}{|c|}{$\mathbf{n = 7 6}$} & $*=$ Multiple response \\
\hline
\end{tabular}

Source: Field survey, 2015

*= Multiple response

\section{Constraints to Shea Butter Production Activities}

Perception of the respondents on constraints limiting Shea processing activities in the study area are presented in Table 7 . The result shows that "difficulties in accessing Shea nuts $(\bar{X}=4.84)$ ", "fluctuations in prices of Shea products $(\bar{X}=4.45)$ ", "poor access to water for processing $(\bar{X}=4.34)$ " and "poor and inefficient processing facilities/equipment $(\bar{X}=4.25)$ " ranked highest in that order as perceived constraints to improved Shea butter production activities. "Poor market information $(\bar{X}=3.99)$ " and "poor marketing outlet $(\bar{X}=$ 3.92)" were also perceived as severe constraints to improved butter production activities. Least considered as constraint is "labour scarcity $(\bar{X}=2.93)$ ".

Poor access to Shea nuts for processing in terms of quantity and quality could be attributed to a reduction in Shea tree population especially, those close to human inhabited areas. The depletion as documented is as a result of the Shea tree being a good raw material for charcoal production and firewood, often used as energy source for domestic cooking especially in the study area. This makes it imperative for Shea fruit pickers to travel far out of inhabited areas for areas with higher Shea tree population for the purpose. As such, there are often difficulties in the evacuation of large quantity of picked fruits to either the markets or processing sites. Price fluctuations of Shea products could be attributed to three major factors; biological seasonality in Shea fruit production, quality of butter produced and the unorganised nature of Shea butter producers which make major marketers of Shea products to determine or dictate the prices of the products based on their whims and caprices. It is not surprising that labour scarcity is perceived as the least constraint to shea nut processing as family and communal form of labour are commonly used for butter production.

Table 7: Perceived Constraints to Shea Butter Production Activities

\begin{tabular}{|l|c|c|}
\hline Constraints & $\begin{array}{c}\text { Mean Score } \\
(\square)\end{array}$ & Rank \\
\hline Access to Shea nuts is difficult & 4.84 & $1^{\text {st }}$ \\
\hline Poor access to water for processing & 4.34 & $3^{\text {rd }}$ \\
\hline Access to processing equipment & 3.17 & $9^{\text {th }}$ \\
\hline Lack of technical information & 3.47 & $7^{\text {th }}$ \\
\hline Labour scarcity & 2.93 & $11^{\text {th }}$ \\
\hline Storage & 3.39 & $8^{\text {th }}$ \\
\hline High labour cost & 3.04 & $10^{\text {th }}$ \\
\hline Poor marketing outlet & 3.92 & $6^{\text {th }}$ \\
\hline Poor marketing information & 3.99 & $5^{\text {th }}$ \\
\hline Poor processing facilities/equipment & 4.25 & $4^{\text {th }}$ \\
\hline Price fluctuations & 4.45 & $2^{\text {nd }}$ \\
\hline
\end{tabular}

$n=76$

(Very severe - 5; Severe - 4; Undecided -3; 2 - Not severe; 1 - Not

a constraint at all)

Source: Field survey, 2015

\section{Hypothesis testing}

$\mathbf{H}_{01}$ : There is no significant relationship between respondents' selected socio-economic characteristics and level of butter production.

The result of the chi-square analysis indicates that respondents' years of experience in processing" $\left(x^{2}\right.$ $=17.18 ; p<0.05)$ and "household size" $\left(x^{2}=12.79 ; p<\right.$
0.05) have significant association with respondents' level of butter production. This result reveals that years of experience in shea butter production activities and household size of respondents influence butter production output ability. This implies that experience in shea butter processing is a key factor and household size is important in labour usage for shea butter production. 
Table 8: Relationship between respondents' socio-economic characteristics and level of Butter production

\begin{tabular}{|l|l|l|l|l|}
\hline $\begin{array}{l}\text { Socio-Economic } \\
\text { Characteristics }\end{array}$ & Chi-square & Df & P-level & Decision \\
\hline Age & 26.52 & 4 & 0.085 & Not significant \\
\hline Gender & 6.74 & 1 & 0.199 & Not significant \\
\hline Marital Status & 11.93 & 3 & 0.898 & Not significant \\
\hline $\begin{array}{l}\text { Processing } \\
\text { experience }\end{array}$ & 17.18 & 4 & 0.002 & Significant \\
\hline $\begin{array}{l}\text { Membership of farm } \\
\text { organisation }\end{array}$ & 105.35 & 1 & 0.052 & Not significant \\
\hline Household size & 12.79 & 4 & 0.021 & Significant \\
\hline \multicolumn{5}{|l}{$\begin{array}{l}\text { Significant at } p<0.05 \\
\text { Source: Field survey, 2015 }\end{array}$} \\
\hline
\end{tabular}

\section{CONCLUSION AND RECOMMENDATION}

In Niger State, Shea fruit processors are mainly women within their active years and of low educational status. The women are mainly Muslims and belong to one cooperative society or more with benefits derivable from such membership being credit facilities and provision of labour for processing activities. The study area is rural in nature and has limited social infrastructure. All the women engage in Shea butter production and main sources of labour for the processing activities are the family and communal labour usually provided by group or cooperative members. Also, the women engage in other income generating activities such aspetty trading and farming.

Butter production levels of the women per month are very low considering the level of work done in the realisation of Shea butter. Gross average monthly income from Shea processing activities fall between $\mathrm{N} 6,000$ and $\mathrm{N} 30,000$ which, when compared to the input requirement for the processing activities, is low.

A major revelation of the study is that Sheanut processing capacity and output of the processors can be increased to between 41 and 100 percent with introduction of improved processing facilities and availability of ready market for the kernel and Shea butter. Most significant constraints to Shea processing activities are difficulties in accessing Shea nuts and price fluctuation for Shea products. The level of education and household size of the respondents influence shea butter production level.

It is thus recommended that deliberate attempt should be made by extension at exposing the processors to improved procedure and technique of Shea butter production from best practices for good quality shea nut production to premium shea butter production as well as shea butter storage methods. Also, improved, affordable and gender friendly processing equipment should be developed through research and introduced to the study area for increased production output and income for the female dominant processors. The processors should be better organised and trained on simple marketing strategy to be relevant in the shea product marketing trend. The Niger State
Ministry of Agriculture and the State Agricultural Development Programme (ADP) should also intensify provision of extension services to the women shea butter processors in the State. Finally all efforts should be put in place at domestication of the Shea tree in Nigeria through production of high yielding variety of shea tree with a reduced gestation period from 25 years to 4-6 years. This will ultimately improve processors access to shea fruits, generally encourage shea butter production and agitate entrepreneurial activities in the shea production industry.

\section{REFERENCES}

Abbiw, D., 1990. The Useful Plants of Ghana. Intermediate Technology Publication/Royal Botanical Gardens, London/ Kew. 337.

Bonkoungou, E., 1987. Monographic du karate Butyrospermum paradoxum (Gaertn. F.). Hepper, espece agroforestiere a Usage Multiple. Institute de Recherche en Biologie et Ecologie Tropicate. Quagadougou Burkina faso. 67.

CABI., 2003. Introgression from Genetically Modified Plants into Wild Relatives and its Consequences, ed. / H.Nijs; D. Bartsch.

Lovett, and Haq. N., 2000. Evidence for Anthropic Selection of the Shea nut tree (Vitellaria paradoxa). Agroforestry Systems 48:273 - 288.

National Population Census., 2007. Population Census interim report. A publication of the National Population Commission, Abuja. 